\title{
Leadership Communication Among Youth Leader in Malaysia
}

\author{
Mohd Hazlami Jusoh ${ }^{1, *}$, Mohd Yusri Ibrahim ${ }^{1}$, Che Hasniza Che Noh ${ }^{1}$, Tuan \\ Norbalkish Tuan Abdullah ${ }^{1}$, Nurhazilah Mamat ${ }^{1}$, Nik Anis Suhailah Nik Mohd ${ }^{2}$, and \\ Siti Khatijah Yasin ${ }^{2}$
}

\author{
${ }^{1}$ Universiti Malaysia Terengganu (UMT), Terengganu, Malaysia \\ ${ }^{2}$ Universiti Sultan Zainal Abidin (UniSZA), Terengganu, Malaysia \\ *Corresponding author email: p2984@pps.umt.edu.my
}

\begin{abstract}
Previous studies showed that leadership and communication practices are the important components that must be possessed among successful leaders. The components are known as the capability of the leaders to get engage and connect with others in organizations. To be a success leader, a mastery of the communication and leadership skills become the vital towards the leadership communication, which should not be missed by the youth today. Despite of this, the mastery towards the skills among the youth is found in unsatisfactory level. Thus, it is important for the youth to master the skills in more depth, critical and focused. The leadership communication among the youth is not only measured through the skills of handling the leadership process at the upper and lower levels, but it also involves in the holistic matters. Therefore, this article is aimed to discuss the concept of leadership communication among the youth, which stresses on interpersonal and persuasive communication skills and problem-solving skills. These skills are found as vital among the youth towards the effectiveness in organization leadership either as an individual, communities, and societies. It becomes a measure among the youth in conducting a successful leadership process towards the future.
\end{abstract}

Keywords: leadership communication, communication skills, organization leadership, the youth

\section{INTRODUCTION}

Communication is a basis aspect in human beings because it is an interaction process to connect and to engage in conveying certain message to each other. In the organization context, it stresses on the communication effectiveness which derived from the leader, which involves of leadership and communication skills. This is because the ineffectiveness communication skills may contribute to the inaccurate information [1]. Thus, it would affect the communication process to become smooth and clear. In line with this, to develop a success organization, those who are leading should aim on the importance of leadership communication as a basic element for a success leader.
The leadership communication skill is recognized as an indicator that should be possessed by the leaders. It is important for leaders to see this as a main source towards success [2], because it gives the impact to the leadership effectiveness [3]. In this context, the youth is recognized as a significant group towards the initial process of leadership communication. Related to this, in Malaysia, there are various initiatives provided to develop the human capital in achieving the quality required among the youth. Therefore, the Malaysian Youth Council [4] stated that the leadership action is important as the main driver towards the youth development. The awareness towards the development is seen as a vital of success among the youth 
in sustaining the future success. This is parallel to the main goals led by the country in developing the youth to become more guided and skilled through leadership communication.

In Malaysia, the youth is also recognized as precious generation towards the prosperous nation, which are having spirit and willingness that contributes to various noble values in society [5]. In this context, they are hoped to hold the responsibility, confidence, capability, active and efficient in various aspect of life [6]. Therefore, it should be emphasized and nurtured among the youth to ensure the organizations led by them run well, which need the practises of effective communication developed by the leaders [7]. Here, the need of being wise among the leaders is important in leading the communication with the members in the organization, so that it will reach the effectiveness of it. The effective leadership communication demonstrates the smooth process of the management in the organization, yet, contributes to the individuals' and communities' well-being.

Although the youth is expected to be leadership model in the nation, but the process in the leadership development among them is still seen in minor level. This is due to the Malaysia Youth Index [8] found that the readiness among youth to the new talent leadership development as in the moderate level. Therefore, to be a success leader, the youth should have a greater performance in communication skills. In this context, the leaders need to be able to lead in every stage of management, from the lower to the upper level of the organization.

This article reviews and discusses the concept of leadership communication among youth leaders in the organizations. Among the components of leadership communications, it involves of interpersonal communication, persuasive communication and problemsolving skills practiced by youth leaders in carrying out the leadership process through communication to the led members. This process plays a big role for the success of the organization, yet, for others and community. Therefore, previous studies indicated that it is important to review and focus more deeply on leadership communication.

\section{LITERATURE REVIEW}

\subsection{Leadership Communication}

Previous studies showed the leadership communication is an important element among people or in organization [1]-[2], [9]-[11]. Most studies showed the communication is a basic component by leaders to interact each other. In completing the leadership process, a leader should mastery these communication skills to ensure the effectiveness of information delivery in organization where the leaders need to have the ability to communicate well with the members. However, leaders who communicate not only communicate continuously, but they are good communicators [2].

Leadership is the position, function and ability to lead others to success [12]. The leaders are responsible for managing their organization effectively. At the same time, leaders should be inspiration by employees in organization [1]. As a leader, they need to show as the best role model by his followers. Therefore, leaders need to use their own charisma and attractiveness by using the basic knowledge, strength and courage as way to influence their followers [13]. These leadership characteristics are able to increase the level of confident among the members to their leaders.

Canary [14] has defined leadership communication as an action to motivate individuals or groups to achieve specific task by motivating, directing and managing the goals. In this aspect, a full of network is used of communication skills and resources intended to deliver messages to control, direct, motivate and inspire for action [15]. However, leadership communication does not involve the individuals in leadership process only [16], but leadership communication is the position of a leader to manage the existing conflicts when there are problems, confusions and issues in the organization.

Leadership communication is the way a leader to communicate with their followers [17]. This connection is encouragement to followers to achieve the same goals and objectives which a leader should make strategic and effective planning through the communication process. At the same time, the communication process should involve clear, accurate, informative communication with continuous message delivery to member. In fact, leaders need act as good democratic leaders by listening to the points, problems, ideas and opinions suggested by their members through the process of discussion in the organization. This situation makes good interpersonal processes with two-way communication. Therefore, a good planning is important to form a collective with members and ensure the smooth of entire system in organization to achieve the desired objectives.

Organizational leaders need to understand and identify organizational culture to build the effectiveness of leadership communication structures. Thus, a leader needs to implement strategies, make decisions and values on communication skills [18], which a leader should communicate with discussion [19]. In this aspect, leaders as a facilitator play a role in communicating with members of the organization by identifying individuals, 
participating in dialogues, asking questions, listening, sharing, reporting and recording all views, gaining consensus and writing reports on discussions between them.

Leadership communication not only involves how the leader communicates, but it is process that involves leadership behavior by the leader to interact with others. So, leaders must be wise in managing and handling problems that exist in organizations, associations, societies, communities or other individuals. Therefore, a leader must have specialized communication skills such as interpersonal and persuasive communication and problem-solving skills that should be held on the shoulder of a leader for the success of the led organization.

\subsection{Interpersonal Communication}

Every day we communicate with each other both verbally and non-verbally in daily conversation, anyone and anywhere. This connection also exists in reality or virtually. In line with the development of telecommunication technology with rapid growth of cyber physic systems under the Industrial Revolution 4.0, the communication process is also evolving rapidly. Humans are now more connected through social networking applications such as Facebook, WhatsApp, Telegram, Twitter, Skype and others. This situation is easier for humans than previous traditional connection processes like limited calls and letters.

In previous communication study widely discussed the concepts of communication. Therefore, communication involves a process of transferring information from sender to receiver [20]. This process occurs when people interact with each other to deliver message, ideas and emotions expressed through the process of communication. In line with that, Barret [15] has stated communication is the delivery of meaning to an individual to another individual. Barret [15] also point out simple of communication process through rhetorical situation consisting of context, sender, message and receiver. This process involves individuals, groups and organizations by sending information to others individuals, groups and organizations which serve as recipients of messages [21] [22]. At the same time, communication involves the sharing of meaning that includes information (facts), ideas (concepts and suggestions) and feelings (personal feelings) [23].

Interpersonal communication exists through a two-way interaction process either with one or more individuals or in groups. According to Barger [24], interpersonal communication is a social bonding which talking and sharing with others serves as a bonding function. Petrovici and Dobrescu [25] added interpersonal skills represent key elements contribute to the building of positive interactions and also ensure social cohesion. However, in an organization, interpersonal communication exists when a leader communicates with members and the member communicates with other members either by conversation or discussion. For example, in youth associations, leaders interact to share information, ideas and tasks to member to plan activities and programs within their association.

\subsection{Persuasive Communication}

Proper communication processes play an important role in understanding what a person wants to convey. This is to ensure the effectiveness of information delivery and the listener feels confident in what someone wants to deliver. The focus on individual communication is emphasized in the context or persuasion that aims to increase someone confidence in the clarity of the message delivered [26]. According to Taillard [27], persuasion is a communicative action that involves two purposes, namely the audience to understand the speech and believe the delivered. In fact, the right method of persuasion also depends on how the individual speaking, content and language of message during the communication process.

Persuasive communication is a way of stimulating behavior [28]. Campbell [29] also states the main purpose of persuasive communication is to produce attitudes and eventually make a change in behavior. The behavioral changes occur from a person's response to another individual who delivers a message capable of changing the listener's behavior to make decisions. However, Dima and Vlăduţescu [30] emphasize that people communicate not only argue or democratize, but they communicate to share experiences, agreement some value, prices, actions, disseminate knowledge, consensus opinions, attitudes and behaviors.

Persuasion embraces appeals to argument and logic [30]. The aim of persuasion is to believe in what you want to convey. Nowadays, persuasive communication abounds in advertising on television, radio or internet, its content to attract people who watch and hear the advertisement. Otherwise, in organization persuasive communication by leaders is vital to encourage members to improve their organization. Leaders take action by interacting with their members by motivating, supporting, encouraging, giving advice, appreciation and inspiration and always fostering understanding with their members. This situation allows members to improve themselves and strive to build the success of the organization to achieve goals and objectives. 


\subsection{Problem Solving Skills}

Problem solving is a mental process used to obtain the "best" answer to an unknown or some decision subject to a set of constraints [31]. Add Wood [31], someone needs knowledge and information to solve the problems. These skills require a process based on knowledge that includes content in the problems such as the ability to identify, locate, obtain, creativity, interpersonal and group skills, communication skills and others [31]. Basadur et al. [32] also described there must be creativity as a brain-storming to solve the problems. In this context, leaders need to have a soft skills and critical thinking to find the best solution in problem solving. Finally, all the problems exist in the organization can be managed and handled by the leaders with these approaches and skills to achieve the objectives of the organization.

Problem solving skills are specific skills for resolving a problem that exist either outside or inside the organization. However, in the way to solve the problems, the leaders can communicate properly with their members. According to Mumford et al. [33], in organization, it is more important to find a solution that can be implemented at the right time with a truly best solution. In addition, Esa and Dolah [34] explain someone needs to have a problem-solving skill by choosing the best alternative and evaluate the effectiveness of the chosen alternative. At the same time, organizational leaders need to find initiatives to address all constrains and conflicts with members of the organization. For example, youth leaders need to discuss, listen, monitor, communicate, share, get information from members of the association, get feedback and lastly leaders try to settle the problems with proper solutions.

\section{CONCEPT MODEL}

Based on previous studies, leadership communication skills among youth leaders are emphasized through specific communication aspects in an organization under youth leadership. These communication skills include interpersonal and persuasive communication and problem-solving skills. The suggestion of concept model is illustrated through the criteria of the variable shown in Figure 1.

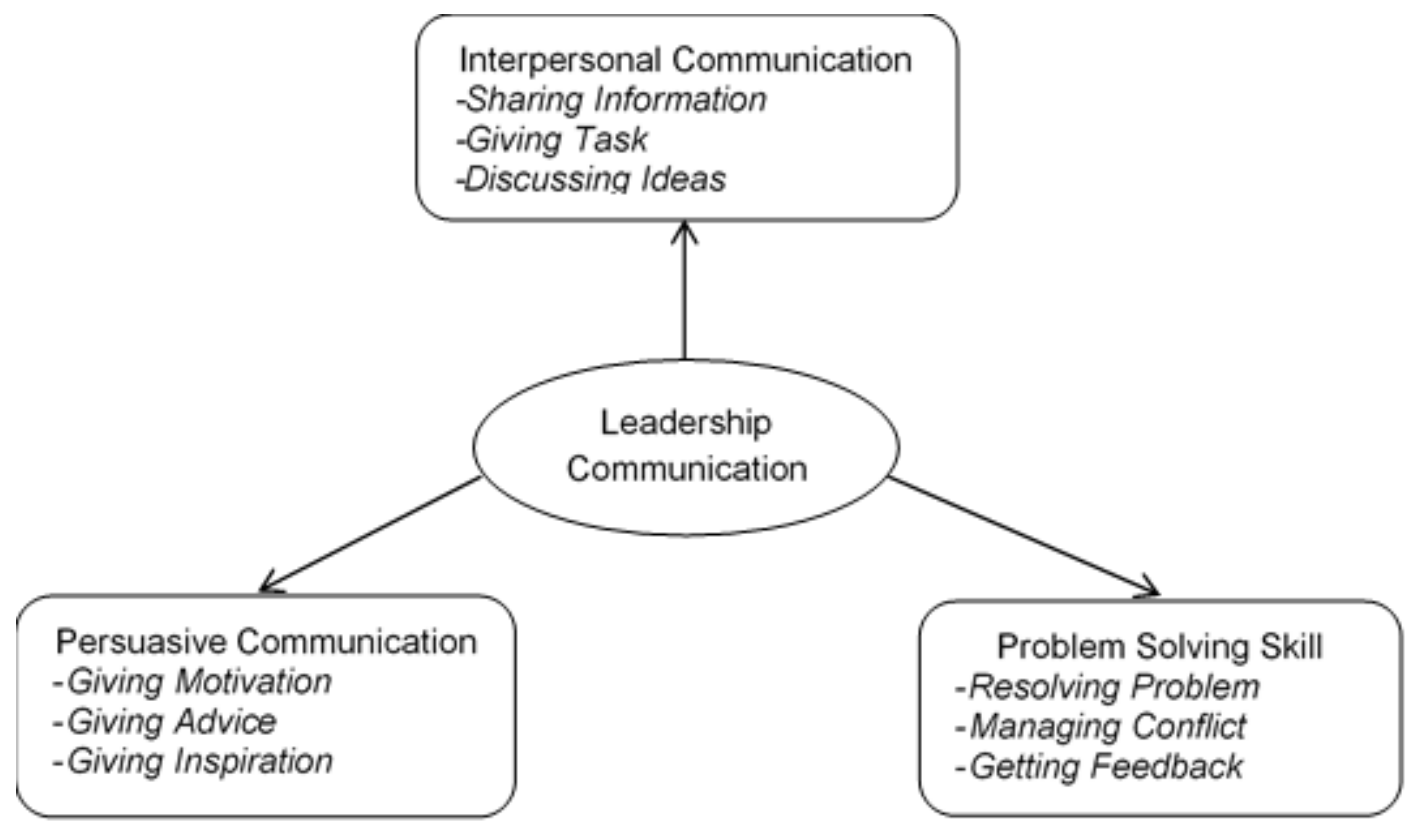

Figure 1 Leadership Communication Skills among Youth Leader

In this concept model, youth leadership communication skills are illustrated through youth organizations or associations which stresses on interpersonal communication, persuasive communication and problemsolving skills. In this aspect, the youth leader interacts with the members of the organization. Interpersonal communication in the context of this study includes sharing information, giving tasks and discussing ideas. Meanwhile, persuasive communication aims to stimulate members to develop organization in a better direction, with the leader giving motivation, advice and inspiration. On the other hand, problems solving skills are a way for leaders to solve the problems that exist in the organization through specific initiatives and approaches. In this aspect, 
the leader can monitor and discuss with members, manage conflicts properly and get feedback from members on problems occurring in the youth organization.

\section{RESULTS AND DISCUSSION}

In the Malaysia context, there are studies on leadership communication conducted by researchers. Ab Ghani et al. [7] conducted a study on leadership communication in Islamic youth organizations. The emphasis of the study was carried out through the leadership communication approach in preaching strategy of Malaysian Islamic Youth (ABIM) in 1972 to 2004. The results showed the role of leader of ABIM use leadership communication approach to deliver the preaching to the Malays in Malaysia until 2004 is very effectively. ABIM also received the support of Malays Community in the growing appreciation of Islamic values through leadership communication approaches.

Amin et al. [11] conducted a study to determine the leadership communication and empowerment towards motivation of civil servants in Kuala Terengganu, Malaysia. The study focuses at Government Sectors and Statutory Corporations. The results indicate leadership communication had a positive significant relationship with empowerment. The results also found the leaders practices open communication can improve the performance of employees to perform the responsibilities in the organization. Besides, Hassan and Ai [35] also conducted the relationship between leadership communication practices and organizational commitment in the Institute of Higher Education in Klang Valley, Malaysia. The results of the study showed positive and significant relationship between leadership communication practices towards organizational commitment which includes effectiveness, continuity and normative commitment.

Rahman et al. [36] also conducted a study related to leadership communication in organization. The study was carried out to get a deep understanding and comprehensive on the process of leadership communication practices in organizations that practice of management quality. The study was conducted in three organizations that have obtained MS ISO 9001 certification. The results have found that leadership communication depends on the situation in the organization by improving the characteristics of leadership communication towards top management and subordinate. In another study, Rahman et al. [37] have conducted a study related to organizational leadership communication in Islamic context. The study emphasizes the aspect of the leader who should be example and role model to the people that includes the aspect of style, methods and communication strategies used by the leaders. However, this study only emphasizes on the concepts used and interpreted on leadership communication in the Islamic context only.

\section{CONCLUSION}

This study is aimed to discuss the concept of leadership communication among the youth leader in organizations, which stresses on interpersonal and persuasive communication skills and problem-solving skills. Previous studies showed leadership communication is significant predictor for other organizations behaviors. This is because the leadership communication is an essential entity for leaders to carry out the leadership process. Therefore, in this aspect youth leaders should emphasize the leadership communication practice with the communication skills possessed by leaders. However, youth leaders not only be wise in communicating with members in organizations such as share the information, discuss ideas and give tasks, but the leaders should nurture the members with values and knowledge that can improve the performance of the organization. As the best icons, youth leaders need to encourage members with motivation, advice and inspiration because leaders are the good example to members. In line with that, leaders should sensitive to the problems that exist outside or inside the organization by taking the initiatives to solve the problems such as listening, monitoring, sharing and getting feedback from members and managing and dealing with conflicts in organization with proper communication skills.

The failure of the leader to practice effective communication and lack of exposure communication knowledge will have negative impact on the smoothness of leadership process in the organization, which leaders have not been exposed to these skills from the beginning. Thus, it is important for youth to master these communication skills. To carry out the leadership process in organization, leaders need to use approaches where the leaders need to build a good connection among the members, create positive feedback and use the psychological element by being a good listener. At the same time, good relationships between superior and subordinate should be maintained by all members to sustain the successful of organization.

Every youth can be a leader, but can they be a great leader? In order to improve of the leadership communication skills among the youth, the efforts and 
strategies should be implemented by the government or association to enhance the capacity and competence of youth in communication skills. The government and associations play an important role in planning activities, programs and workshops to youth societies at the university or community level which includes filling of soft skills such as communication, leadership, critical thinking and self-management skills, teamwork and others. These elements are found as vital among the youth because youth will be a leader to the community, race and country in the future.

\section{ACKNOWLEDGMENT}

The authors express their sincere thanks to the Universiti Malaysia Terengganu.

\section{REFERENCES}

[1] A. T. Haslan, N. M. Nordin, G. Darusalam, Amalan Komunikasi Kepimpinan dalam Mempengaruhi Kepuasan dan Komitmen Guru: Kajian di SekolahSekolah Menengah Daerah Bentong. Seminar Antarabangsa Isu-Isu Pendidikan (ISPEN2018), 5 July, 2018, Universiti Malaya, (2018).

[2] R. Ishak. Komunikasi Kepimpinan dalam kalangan Pemimpin Sekolah. Jurnal Komunikasi Borneo Edisi Khas (Konvokesyen ke-19 UMS), (2017).

[3] A. Luthra, R. Dahiya, Effective Leadership is All about Communicating Effectively: Connecting Leadership and Communication. International Journal of Management \& Business Studies (IJMBS), 5 (3) (2015), 43-48.

[4] Malaysia Youth Council, Mendepani Cabaran Kepimpinan Belia, (2015).

[5] E. C. B. A. Ungan, H. Ahmad, Penilaian Asean Youth Volunteer Programme (AYVP) 2018 dan Kesannya kepada Pembangunan Diri dan Kesukarelawanan. Jurnal Wacana Sarjana, 4 (1) (2020), $1-15$.

[6] M. Y. Ibrahim, Pengaruh Amalan Komunikasi terhadap Penglibatan Belia dalam Kesukarelawanan (The Influence of Communication Practices on Youth's Participation in Volunteerisme). Geografia-Malaysian Journal of Society and Space, 13 (4) (2017), 80-92.
[7] S. R. Ab Ghani, R. Omar, A. M. Enh, R. Kamaruddin, Pendekatan Komunikasi Kepemimpinan dalam Strategi Berdakwah Angkatan Belia Islam Malaysia (ABIM) 1972-2004. Jounal of Social Sciences and Humanities, 17 (5) (2020), 202-219.

[8] Malaysia Youth Index, Institut Penyelidikan Pembangunan Belia Malaysia. Putrajaya: Kementerian Belia dan Sukan Malaysia, (2015).

[9] V. Miftari, Transformational Leadership Communication in Developing Countries' Business Environment. Journal of History Culture and Art Research, 7 (2) (2018), 259-264.

[10] M. H. Abbasi, A. Siddiqi, R. U. A. Azim, Role of Effective Communications for Enhancing Leadership and Entrepreneurial Skills in University Students. International Journal of Business and Social Science, 2 (10) (2011).

[11] W. A. A. W. M. Amin, M. S. Muda, N. W. Omar, W. S. W. Abdullah, Penentu Komunikasi Kepimpinan Dan Empowermen Terhadap Motivasi Kakitangan Awam Di Kuala Terengganu. Journal of Techno Social, 1 (1) (2009).

[12] S. H. Ayub, N. A. Manaf, M. R. Hamzah, Leadership: Communicating Strategically in the 21st Century. Procedia-Social and Behavioral Sciences, 155 (2014), 502-506.

[13] E. N. Chapman, S. L. O’Neil, Leadership: Essential Steps Every Manager Needs to Know (Third Edition). Prentice-Hall, (2000).

[14] H. E. Canary, Communication and Organizational Knowledge: Contemporary Issues for Theory and Practice. Florence: Taylor \& Francis, (2011).

[15] D J. Barrett, Leadership Communication. New York: McGraw-Hill, (2008).

[16] M. Siitonen, Conflict Management and Leadership Communication in Multiplayer Communities. In Proceedings of DiGRA, (2009).

[17] J. Baldoni, Leader to Leader. Spring, 32 (2004), 20-24. 
[18] B. Zulth, Leadership Communication in a Project Management. Procedia-Social and Behavioral Sciences, 119 (2014), 172-181.

[19] M. Y. H. Abdullah, N. R. A. Bakar, J. Sulehan, A. H. Awang, O. P. Liu, Komunikasi dan Pembangunan Komuniti Peringkat Desa: Berkongsi Pengalaman antara Indonesia dengan Malaysia. Jurnal Melayu, 6 (2011), 227-237.

[20] D. C. Andrews, W. D. Andrews, Management communication: A Guide. Cengage Learning, (2004).

[21] J. Greenberg, R. A. Baron, Behaviour in Organizations (6th Edition). London: Practice Hall, (1996).

[22] A. Gode, What is Communication. Journal of Communication, 9 (1) (1959).

[23] J. Adair, N. Thomas, The Consise Adair on Communication and Presentation Skill. Edited by Neil Thomas, (2008).

[24] J. Berger, Word of Mouth and Interpersonal Communication: A Review and Directions for Future Research. Journal of Consumer Psychology, 24 (4) (2014), 586-607.

[25] A. Petrovici, T. Dobrescu, The Role of Emotional Intelligence in Building Interpersonal Communication Skills. Procedia-Social and Behavioral Sciences, 116 (2014), 1405-1410.

[26] Z. Aini, A. G. Don, A. I. Mokhtar, N. U. A. Fauzi, Strategi Komunikasi Pemujukan Pendakwah dalam Penyampaian Mesej Islam kepada Masyarakat Orang Asli di Selangor. Al-Irsyad: Journal of Islamic and Contemporary Issues, (2019), 12-26.

[27] M. O. Taillard, Persuasive Communication: The Case of Marketing. Working Papers in Linguistics, 12 (2000), 145-174.

[28] S. M. Burn, S. Oskamp, Increasing Community Recycling with Persuasive Communication and Public Commitment. Journal of Applied Social Psychology, 16 (1) (1986), 29-41
[29] J. M. Campbell, Changing Children's Attitudes toward Autism: A Process of Persuasive Communication. Journal of Developmental and Physical Disabilities, 18 (3) (2006), 251-272.

[30] I. C. Dima, S. Vlăduţescu, Persuasive Communication in Logistic Negotiation. International Journal of Economical Research, 3 (1) (2012), 14-21.

[31] D. R. Woods, How Might I Teach Problem Solving?. New directions for Teaching and Learning, 30 (1987), 55-71.

[32] M. Basadur, P. Pringle, G. Speranzini, M. Bacot, Collaborative Problem Solving through Creativity in Problem Definition: Expanding the Pie. Creativity and Innovation Management, 9 (1) (2000), 54-76.

[33] M. D. Mumford, S. J. Zaccaro, F. D. Harding, T. O. Jacobs, E. A. Fleishman, Leadership skills for a changing world: Solving complex social problems. The Leadership Quarterly, 11 (1) (2000), 11-35.

[34] A. Esa, N. A. Dollah, Adoption and Awareness Students to Skills Development of Problem Solving in Club of Counseling and Career UTHM. Prosiding Persidangan Pembangunan Pelajar Peringkat Kebangsaan, (2013), 633-640.

[35] M. S. Hassan, C. Y. Ai, Relationships between Leadership Communication Practices and Organisational Commitment in a Selected Higher Education Institution. Pertanika Journal of Social Sciences \& Humanities, 16 (1) (2008), 15-29.

[36] R. A, R. R. Rahman, M. A. B. Yusof, A. Yahaya, M. S. Hassan, Pelaksanaan Komunikasi Kepemimpinan dalam Organisasi Pengamal Pengurusan Kualiti Msiso 9001 di Malaysia, (2010).

[37] R. A, R. R. Rahman, A. Yahaya, M. S. Hassan, Peranan Komunikasi Kepemimpinan Diri dan Organisasi dalam Perspektif Islam. Seminar Kebangsaan Kemahiran Insaniah dan Kesejahteraan Sosial, (2008), 1-15. 